\title{
The migration game in habitat network: the case of tuna
}

\author{
Patrizio Mariani · Vlastimil Křivan · Brian R MacKenzie · Christian Mullon
}

Received: date / Accepted: date

\begin{abstract}
Long distance migration is a widespread process 18 2 evolved independently in several animal groups in terrestrial and marine ecosystems. Many factors contribute to the mi- 20 4 gration process and of primary importance are intra-specific competition and seasonality in the resource distribution. Adap6 tive migration in direction of increasing fitness should leads ${ }^{22}$ to the ideal free distribution (IFD) which is the evolutionary 8 stable strategy of the habitat selection game. We introduce a migration game which focuses on migrating dynamics that 10 lead to the IFD for age-structured populations in time varying environments where dispersal is costly. The model as12 sumes a network of habitats and predicts migration dynam- ${ }_{26}$ ics between these habitats and the corresponding population

14 distribution. When applied to Atlantic bluefin tunas it pre- ${ }_{28}$ dicts their migration routes and their seasonal distribution.

16 The largest biomass is located in the spawning areas which ${ }_{30}$ have also the largest diversity in the age-structure. Distant
\end{abstract}

P. Mariani

Centre for Ocean Life, National Institute for Aquatic Resources, Tech- 34 nical University of Denmark, Jægersborg Allé 1, 2920 Charlottenlund Denmark

Tel.: +45-35883353

Fax: +45-35883333

E-mail:pat@aqua.dtu.dk

V. Křivan

Biology Centre AS CR, Institute of Entomology, and Department of 40 Mathematics and Biomathematics, Faculty of Science, University of South Bohemia, Branišovská 31, 37005 České Budějovice, Czech Re- ${ }_{42}$ public

B.R. MacKenzie

Center for Macroecology, Evolution and Climate, National Institute for Aquatic Resources, Technical University of Denmark, Jægersborg Allé

1, 2920 Charlottenlund Denmark

C. Mullon

IRD, Unité de Recherche Ecosystémes Marins Exploités, Avenue Jean Monnet, 34200, Séte, France feeding areas are occupied on a seasonal base and often by larger individuals, in agreement with empirical observation. Moreover we show that only a selected number of migratory routes emerge as those effectively used by tunas.

Keywords Structured population, ideal free distribution, game theory, habitat selection, bluefin tuna

\section{Introduction}

Many populations of animals and plants exhibit characteristic distributional patterns that are related to the ability of the organisms to move and explore their environment. Changes in the environment can elicit individual reactions, hence causing different spatial distributions of populations (Morris, 2011). Competition is among the major driving forces shaping animal distributions. Dispersal from more populated to less populated habitats reduces intra- and inter-specific competition thus promoting species coexistence and diversity (MacArthur and Levins, 1964; Rosenzweig, 1981). These dispersal dynamics often involve active habitat selection, which is a widespread phenomenon in nature and has been described in many animal populations such as birds (Cody, 1985), terrestrial mammals (Wecker, 1963) and fish (MacCall, 1990).

Fitness based arguments are commonly used to describe the process of habitat choice (MacArthur and Levins, 1964). When moving between different habitats, organisms should prefer those sites that provide them with the highest payoff, i.e., where their fitness is maximised (Rosenzweig, 1981). Nevertheless, both individual fitness and habitat selection typically depend on interactions between individuals, which usually have the form of a density dependent relation linking habitat quality and species distribution (Rosenzweig and Abramsky, 1985).

Under negative density dependence (described by logistic growth), if dispersal is cost free and individuals are om- 
bioRxiv preprint doi: https://doi.org/10.1101/020743; this version posted June 10, 2015. The copyright holder for this preprint (which was not certified by peer review) is the author/funder, who has granted bioRxiv a license to display the preprint in perpetuity. It is made available under aCC-BY-NC-ND 4.0 International license.

niscient and free to settle at any habitat, the evolutionar- 54 2 ily stable strategy corresponds to the ideal free distribution (IFD) (Fretwell and Lucas, 1969; Křivan et al, 2008; Morris,

4 2011). At the IFD, payoffs in all occupied habitats are the same and larger or equal than those in the unoccupied habi- ${ }^{56}$

6 tats. Thus, no individual can improve its fitness by choosing a different habitat.

Although the IFD is a strong theoretical tool to analyse animals' spatial distributions, over the past decades at- ${ }^{50}$ - tempts to validate it led to equivocal results (Matsumura et al, 2010). For example, several studies reported "under-

2 matching" when animals underuse better patches and overuse poorer patches (for a review see Kennedy and Gray, 1993).

14 These discrepancies between the IFD and observed distributions are attributed to, e.g., the cost of moving (Åström, 16 1994), imperfect information (Matsumura et al, 2010), or stochastic fluctuations in environmental conditions (Schreiber, 8 2012).

An important aspect that is usually neglected in theoretical studies of habitat selection and migration (but see, e.g., Sutherland and Parker, 1985; Hugie and Grand, 1998; ${ }^{66}$

22 Grand and Dill, 1999; Tregenza and Thompson, 1998) is the variability among individuals. In particular, factors re- ${ }^{68}$

24 lated to age or energetic state can contribute to individuals' perception of the environment and affect the ability to mi- ${ }^{70}$ 26 grate between habitats. Moreover, the specific location in which each individual lives can also affect the habitat selec- ${ }^{72}$

28 tion process. Indeed, while the IFD assumes freely moving individuals between habitats, habitat-connectivity can often ${ }^{74}$ be constrained by specific geographical (e.g., topography) or temporal (e.g., seasonal) patterns, which can then limit $^{76}$ the ability to migrate towards better habitats. A network of habitats is often a more realistic and general description of ${ }^{78}$ 34 habitat connectivity for migratory species.

For example, migratory species such as the Atlantic bluefin

36 tuna (BFT) have widely separated feeding and spawning areas that are distributed over a large latitudinal gradient.

38 Those habitats are typically exposed to changes in seasonal- 80 ity and habitat productivity that can affect payoffs and dis-

40 persal dynamics of the habitat selection game. The species ${ }^{82}$ appears to have evolved a migration strategy that alternates

42 rapid movement between neighbouring regions, to periods of continuous feeding in those areas before a new migration

44 occurs (Block et al, 2005, 2001; Wilson et al, 2005). Thus, the dispersal dynamic between distant habitats appears as a

46 multiple step process by which tunas explore several habitats rather than a single direct movement towards higher

48 payoff areas.

In this manuscript we present a game theoretical approach, 50 called the "migration game", to model migration dynamics of an age-structured population on a network of intercon- 84 52 necting habitats that undergo seasonal variation. In addition, we assume a travel cost that is age specific. Then we apply 86 this concept to BFT to predict their seasonal distribution and their migration routes across the Atlantic.

\section{Theoretical framework}

\subsection{The migration game}

We consider an unstructured migratory species in an heterogeneous environment consisting of a network with $n$ habitats. Population and distributional processes are assumed to be discrete in time, and the time step is scaled so that it equals 1 . In each habitat, $i$, and at each time step the population abundance, $p_{i}$, changes due to migration and population dynamics:

$p_{i}(t+1)=p_{i}(t)+f_{i}\left(\sum_{j=1}^{n} p_{j}(t) x_{j i}(t)-\sum_{j=1}^{n} p_{i}(t) x_{i j}(t)\right)$

where $f_{i}$ is the demographic change of the population $p_{i}$ (birth and death processes), and $x_{i j}(t)$ is the per capita migration rate from patch $i$ to patch $j$ within the unit time interval. The model (Eq. 1) assumes that in each time interval dispersal occurs before demographic changes. The total population abundance at time $t$ is $P(t)=\sum_{i}^{n} p_{i}(t)$. Dispersal rates, $x_{i j}(t)$, are non-negative and satisfy $\sum_{j=1}^{n} x_{i j}(t)=1$ for every $i=1, \ldots, n$. We note that $x_{i i}(t)$ is the probability of staying in the patch $i$.

To describe migration rates we assume that each habitat is characterised by a negative density dependent payoff, $u_{i}$. If there is a direct link between habitats $i$ and $j$ in the network, then for individuals migrating from $i$ to $j$ we define a reward function:

$\Phi_{i j}\left(p_{i}, p_{j}\right)=u_{j}\left(p_{j}\right)-c_{i j}-u_{i}\left(p_{i}\right)$

where $c_{i j} \geq 0$ is a cost term for the migration game. This cost includes the energy needed to migrate between habitats $i$ and $j$ as well as the energy required for habitat selection and decision making processes (Bonte et al, 2012).

We consider directed (non-random) movements on the network and we assume that along the migration routes the reward must be non-negative. In other words, an individual currently in patch $i$ will move to patch $j$ only when the reward of doing so is positive. Hence at each time step, $t$, dispersal rates $x_{i j}$ must results in a population distribution satisfying:

$\Phi_{i j}\left(p_{i}, p_{j}\right) \geq 0$.

In the model motility is restricted by the topology of the network and individuals can only migrate between neighbouring habitats (i.e., habitats directly connected by a link). Moreover, the choice of an individual affects migration rates, 
bioRxiv preprint doi: https://doi.org/10.1101/020743; this version posted June 10, 2015. The copyright holder for this preprint (which was not certified by peer review) is the author/funder, who has granted bioRxiv a license to display the preprint in perpetuity. It is made available under aCC-BY-NC-ND 4.0 International license.

$x_{i j}$, and also population distribution ( $p_{i}$, Eq. 1). Hence, the 50 2 rewards $\left(\Phi_{i j}\right.$, Eq. 2$)$ are regulated by the reciprocal strategies of competing individuals.

This defines a non cooperative migration game, in which (1) players are the set of individuals characterised by their ${ }_{52}$ 6 current habitat $i,(2)$ the strategy of the players currently in habitat $i$ is the probability $x_{i j}$ with which the individuals ${ }_{54}$ 8 move to one of the neighbouring habitats, and (3) the reward of the set of players living in $i$ is defined as the average re- ${ }_{56}$ ward $\sum_{j} x_{i j} \Phi_{i j}$ where the sum is only over all neighbouring habitats $j$ (i.e., habitats directly connected to habitat $i$ ).

The equilibrium solutions are migration rates $x_{i j}^{*}$ that are the Nash equilibria (NE) of the migration game. The equilib- 60 rium strategy is such that any unilateral change in the strategy of any individual would results in a lower reward for the 62 16 player who changes its strategy. This implies that for any two habitats $j$ and $j^{\prime}$ such that $x_{i j}^{*}>0$ and $x_{i j^{\prime}}^{*}>0$, the re- ${ }_{64}$ 18 wards must be the same and maximal (i.e., $\Phi_{i j}^{*}=\Phi_{i j^{\prime}}^{*} \geq \Phi_{i k}^{*}$ for any connected habitat $k$ such that $x_{i k}=0$ ). The migra- ${ }_{66}$ 20 tion game is a potential game that guarantees the existence and uniqueness of a NE (Sandholm, 2010). This equilibrium 68 22 can be calculated as the solution of a variational inequality (Nagurney, 1993; Mullon and Nagurney, 2012; Nagur-70 24 ney et al, 1992) or a linear complementary problem (LCP) (Mullon, 2013; Facchinei and Pang, 2003).

Migration rates $x_{i j}^{*}$ are then used in the model (Eq. 1) to define population dynamics on the network.

$28 \quad 2.2$ Distributional equilibrium in a cost-free migration game

We assume that migration is cost free, i.e., $c_{i j}=0$ in Eq. (2), hence the reward function is similar to those used in habitat 80

32 selection games (Hugie and Dill, 1994; Křivan et al, 2008) and the solution of the migration game converges in several ${ }^{82}$ 34 time steps to the IFD (Pan and Nagurney, 1994; Cressman and Křivan, 2006). However, because dispersing animals are ${ }^{84}$ 36 constrained in their movement by links in the habitat network, depending on the topology of the network it can take several steps to reach the global IFD. Indeed at each time step individuals can move only to habitats that are directly ${ }^{86}$ 40 connected to their current habitat. Thus, at each time step individuals reach a local IFD in the sense that directly linked

42 patches have the same payoffs as we do not consider the cost of dispersal. As time increases, the IFD becomes more 44 global, that is, payoffs in additional patches get equalised.

To illustrate the relation between migration equilibrium 46 and distributional equilibrium we consider a simple case of three habitats denoted as $A, B, C$, and two different network

48 topologies: (a) a fully connected network (Figure 1a); (b) a network where $B$ is disconnected from $C$ (Figure 1b). Each habitat is characterised by its payoff:

$u_{i}=1-\frac{p_{i}}{K_{i}}$

where $K_{i}$ is the habitat environmental carrying capacity, $p_{i}$ is the number of individuals in patch $i$ with $i \in\{A, B, C\}$. We assume no migration costs $\left(c_{i j}=0\right)$ and all individuals, $P$, initially occupying habitat $C$ only, i.e., $p_{C}=P, p_{A}=p_{B}=0$.

When the network is fully connected our model converges to the IFD in a single time step (Figure 1a). Since individuals are free to move in all the habitats in the network, the strategies resulting from the migration game are those needed to balance the reward function in Eq. (2) for all the three habitats. This condition is also the condition for the IFD.

When the network is not fully connected, several steps are needed to reach the IFD (Figure 1b). The equilibrium value can be efficiently calculated using variational inequality (Mullon, 2013). In the first step, only movements between $C$ and $A$ are possible on the network and the values of $x_{i j}$ are those balancing the rewards $\left(\Phi_{C A}=\Phi_{A C}\right)$, i.e., a local IFD conditions is reached between the two habitats. In the next step, individuals that are now in habitat $A$ have the possibility to migrate into $B$ since $\Phi_{A B}>0$. But, not all the dispersal rates are possible to reach the equilibrium, since for any given habitat the number of migrants cannot be larger than the number of inhabitants. Indeed, the migration equilibrium $x_{A B}, x_{C A}$ must satisfy constraints $0 \leq x_{A B} \leq p_{A}$ and $0 \leq x_{C A} \leq p_{C}$. The new distribution is again calculated equalising the reward functions in the three habitats and considering that after the migration the payoff in habitat $A$ can be written as

$u_{A}=1-\left(p_{A}+x_{C A}-x_{A B}\right) / K_{A}$

with similar expressions for the payoff in habitat $B$ and $C$. Equilibrium values for $x_{C A}$ and $x_{A B}$ are calculated by equalising the patch payoffs. In particular, at this step all the individuals living in $A$ move into $B$ and a new distribution is reached between $A$ and $C$. At step number three, the equilibrium values for dispersal rates are those satisfying the IFD on the network (Figure 1b).

\subsection{The effects of costs and multiple equilibria}

When travel costs are zero and patch payoffs are negative density dependent there is a single IFD (Křivan et al, 2008). However, if migration costs are positive there may be infinitely many possible IFDs. Indeed, let us consider an environment consisting of two habitats $(i=1,2)$, and let the habitat payoffs be described by the Eq. (4).

The reward of an individual currently in patch 1 to migrate to patch 2 is

$\Phi_{12}\left(p_{1}, p_{2}\right)=u_{2}\left(p_{2}\right)-u_{1}\left(p_{1}\right)-c_{12}$ 
bioRxiv preprint doi: https://doi.org/10.1101/020743; this version posted June 10, 2015. The copyright holder for this preprint (which was
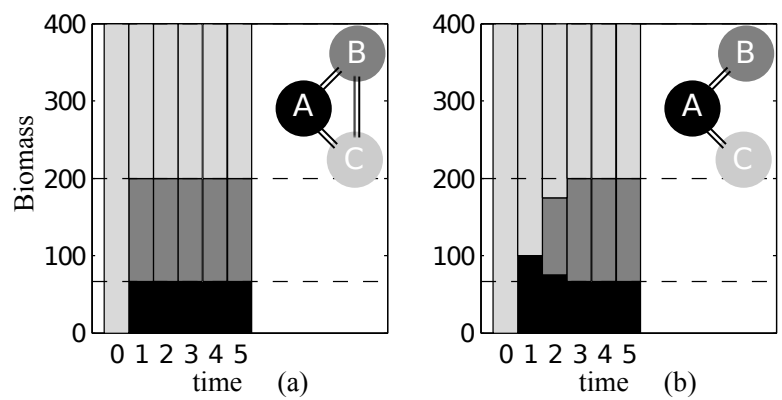

Fig. 1 Cumulative distribution of the migratory population in the three habitats A, B, C in the case (a) all the habitats are connected (b) connections between $\mathrm{A}=\mathrm{B}$ and $\mathrm{A}=\mathrm{C}$. Also shown (dashed lines) the reference cumulative distribution at the IFD. Parameters: $K_{A}=100$, $K_{B}=200, K_{C}=300$ and total population $P=400$.

and, similarly, the reward of an individual currently in patch ${ }_{24}$ 2 to migrate to patch 1 is

$\Phi_{21}\left(p_{1}, p_{2}\right)=u_{1}\left(p_{1}\right)-u_{2}\left(p_{2}\right)-c_{21}$,

Under the IFD none of these two rewards can be positive. In particular, when travel costs are neglected a single IFD exists at which $\Phi_{12}\left(p_{1}, p_{2}\right)=\Phi_{21}\left(p_{1}, p_{2}\right)=0$ (Figure $\left.2 \mathrm{~A}\right)_{28}$ When travel costs are positive (Figure 2B) there is a region of possible distributions under which individuals in neither 6 patch have a positive reward to move. Thus, all these distributions correspond to IFDs.
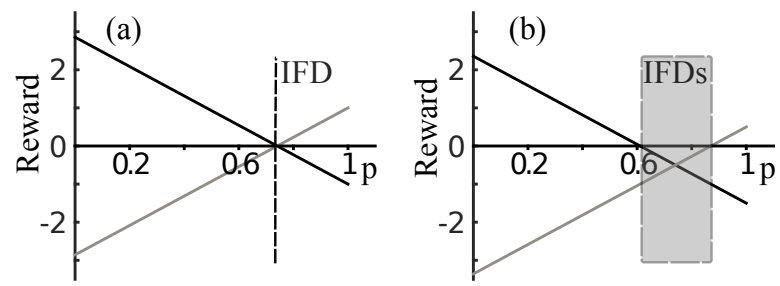

Fig. 2 Reward functions $\left(\Phi_{i j}\right)$ with and without migration costs. The plots show rewards of migration for individuals in patch 1 (red) and in 40 patch 2 (blue) as the proportion $p$ of individuals in patch 1. For values of $p$ such that the red (blue) line is above the $\mathrm{x}$-axis, individuals of population 1 (2) have advantage to migrate. In (a) migration costs are zero and a single equilibrium is present at $p=0.74$. While in (b) migration costs are positive and there is a set of equilibrium distributions 44 $(p \in[0.58,0.84])$.

The LCP method that we use to calculate numerically the NE of the migration game selects a single IFD from the set of possible IFDs, The selected point is on the boundary ${ }^{46}$ of the set of all IFDs, i.e., in the above example it is one of the two boundary points.

\subsection{Coupling migration and demographic processes}

14 We extend the model (Eq. 1, 2) by considering a structured population with several $(S)$ age classes $a$. It can be repre- 54 ${ }_{16}$ sented as $P_{i}(t) \rightarrow P_{i}^{\prime}(t) \rightarrow P_{i}(t+1)$, where $P_{i}(t)=\left\{p_{i, a}\right\}$ is the population distribution, once individuals have redis18 tributed themselves according to the migration equilibrium, and $P_{i}(t+1)$ is the population distribution after the demo-

20 graphic processes (birth, death and growth). To represent these processes, in each habitat, we use a Leslie matrix, i.e., 22 we have $P_{i}(t+1)=L_{i}(t) \times P_{i}^{\prime}(t)$ where:

$$
L_{i}(t)=\left(\begin{array}{ccccccc}
q_{i, 1} & r_{i, 2} & r_{i, 3} & \ldots & r_{i, S-2} & r_{i, S-1} & r_{i, S} \\
g_{i, 1} & q_{i, 2} & 0 & \ldots & 0 & 0 & 0 \\
0 & g_{i, 2} & q_{i, 3} & \ldots & 0 & 0 & 0 \\
\ldots & \ldots & \ldots & \ldots & \ldots & \ldots & \ldots \\
0 & 0 & 0 & \ldots & g_{i, S-2} & q_{i, S-1} & 0 \\
0 & 0 & 0 & \ldots & 0 & g_{i, S-1} & q_{i, S}
\end{array}\right)
$$

The probability that a fish in class $a-1$ at time $t$ will grow into class $a$ at time $t+1$ is $g_{a}$. Similarly, $q_{a}$ is the probability that a fish will continue to stay in the same class, while $r_{a}$ is the average number of newborns (belonging to the class $a=1$ ) produced by individuals at ages $a>1$.

\section{Case Study}

\subsection{The ecology of Atlantic bluefin tuna}

30 The Atlantic bluefin tuna (Thunnus thynnus) has evolved a migratory behaviour in which spawning and feeding sites

32 are separated by large distances, typically spanning 100s1000s of kilometres and several degrees of latitude (Mather 34 et al, 1995; Cury et al, 1998). Spawning sites are located in temperate-tropical waters (i.e., Mediterranean Sea, Gulf of Mexico), but feeding sites used by the largest and oldest individuals are located in northern temperate-boreal waters (Mather et al, 1995). During the narrow reproductive period individuals often display fast trans-Atlantic migrations to reach the Mediterranean spawning ground (Block et al, 2005; Fromentin, 2009). The seasonal south-north migratory behaviour exhibited by bluefin tuna has likely evolved to allow the species to benefit from large biomasses of prey species in these regions (Cury et al, 1998).

\subsection{Model implementation}

We implement the theoretical framework described above, to illustrate the spatial dynamics of the Atlantic Bluefin tuna. The time step for the dynamic system is set equal to one month, and the simulations are extended up to 20 years. We 50 chose a network of $n=8$ habitats (Figure 3): Gulf of Mexico (A), Brazil (B), Maine (C), North Atlantic (D), Norway (E), Bay of Biscay (F), eastern Atlantic (G) and Mediterranean $(\mathrm{H})$. The links between habitats are selected based on historical migration routes of bluefin tuna and defined to represent feasible distances that individuals can cover in one 
bioRxiv preprint doi: https://doi.org/10.1101/020743; this version posted June 10, 2015. The copyright holder for this preprint (which was not certified by peer review) is the author/funder, who has granted bioRxiv a license to display the preprint in perpetuity. It is made available under aCC-BY-NC-ND 4.0 International license.

Table 1 Biological characteristics of age classes

\begin{tabular}{lllllr}
\hline Age class & Weight & Fertility & Growth & Survival \\
$a$ & $w(K g)$ & $r^{a}\left(\right.$ mont $\left.^{-1}\right)$ & $g\left(\right.$ mont $\left.^{-1}\right)$ & $q\left(\right.$ mont $\left.^{-1}\right)$ \\
\hline Young & 1 & 0 & 0.02 & 0.9 & 20 \\
Juvenile & 30 & $0.125 s$ & 0.02 & 0.9 & \\
Adult & 100 & $0.25 s$ & 0.02 & 0.9 & \\
Mature & 200 & $0.5 s$ & 0.02 & 0.9 & 22 \\
Old & 500 & $s$ & 0.02 & 0.9 & \\
\hline
\end{tabular}

month. Moreover, the migratory population is structured in 26 five classes (age, $a$ ): young of the year, juvenile, adult, mature and old. We denote by $w_{a}$ the mean weight of tuna at age class $a$ (Table 1 ).

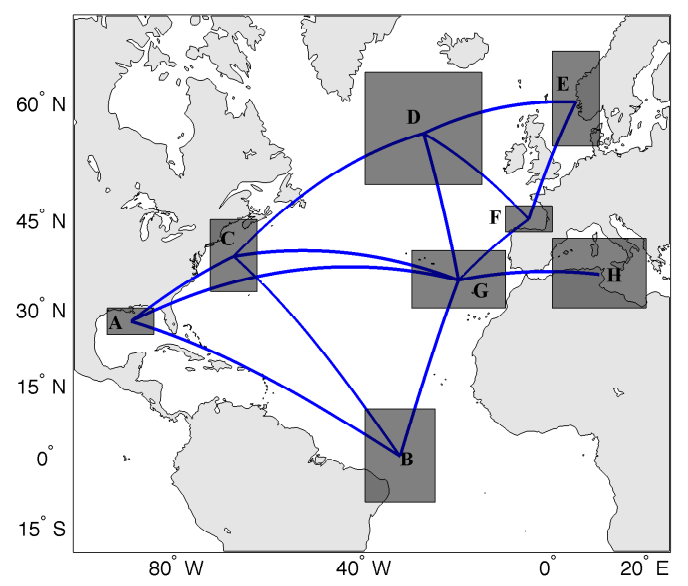

Fig. 3 Network for the bluefin tuna migration game. We consider $8_{44}$ habitats: A: Gulf of Mexico, B: Brazil, C: Maine, D: North Atlantic, E: Norway, F: Bay of Biscay, G: Eastern Atlantic, H: Mediterranean. Habitats are defined within a certain spatial range (grey areas) for which we calculate the average biological productivity which is assumed proportional to the habitat's carrying capacity. Links between habitats indicates the potential migration routes assumed in the present study.

Patch payoffs for an individual of class $a$ in habitat $i \in$ 6 $\{A, \ldots, H\}$ at month $t$ are density dependent:

$u_{i}=1-\frac{\sum_{a} w_{a} p_{i, a}}{K_{i}}$

where $p_{i, a}$ is the population of age $a$ living in habitat $i ; K_{i}$ 8 is the time varying carrying capacity of habitat $i$ described as $K_{i}(t)=K_{i}\left(1-\theta_{i} \cos (t \pi / 2)\right)$, with $\theta_{i} \leq 1$, being a season-

10 ality parameter specific for each habitat (Table 2$)$. The seasonality parameter is calibrated using averaged data (2003

12 - 2011) of seasonal variability of the biological productiv- 4 ity (Westberry et al, 2008) averaged over the area covered 14 by the habitat (Figure 3). Larger coefficients reflect larger seasonal fluctuations typically at higher latitudes.
The costs for exploring adjacent habitats, $c_{i j}$ in Eq. 2, are difficult to set. This is because the term includes several processes such as traveling between habitats, comparison of habitat qualities and decision making process to select one specific habitat (Bonte et al, 2012). Tuna are efficient swimmers (Dewar and Graham, 1994) and can travel thousand of kilometres within few days (Block et al, 2001). Hence, the cost of traveling and exploring different habitats is not negligible but probably low and most likely dependent on the distance between habitats. Indeed we assume here that the cost for habitat identification and selection is a function of the distance between habitats and approximate it as:

$c_{i j, a}(t)=\mu \frac{d_{i j}}{w_{a}^{0.06}}$

${ }_{28} \quad$ where $d_{i j}$ is the distance in kilometres between habitat $i$ and $j$, while $w_{a}$ is the age specific average weight, which we

so assume is proportional to the individual swimming speed. We consider migrations performed at an optimal velocity and it can be shown (Appendix A) that for tunas the swimming speed scales as $w_{a}^{0.06}$ (Ware, 1978). We set the range of 34 $\mu=5-150$ to analyse migration game under different habitat selection costs, and we test the sensitivity of our results to this parameter.

The demographic rates in the Leslie matrix (survival $q_{a}$, 38 fertility $r_{a}$, growth $g_{a}$; Eq. 6) are given in Table 1. Fertility coefficients, $r_{a}$, are non zero only in the spawning areas:

40 Gulf of Mexico (A) and Mediterranean (H). In our definition of the Leslie matrix (Eq. 6) we assume that older individuals 42 have higher fertility proportional to some spawning intensity $s$. In the model we test how the results are affected by different values of $s$ (Appendix A).

Table 2 Characteristics of habitats

\begin{tabular}{rcc}
\hline Habitat $i$ & $\begin{array}{c}\text { Mean carrying } \\
\text { capacity } K_{i}\end{array}$ & Seasonal effect $\theta_{i}$ \\
\hline Gulf of Mexico (A) & 130.000 & 0.2 \\
Brasil (B) & 20.000 & 0.1 \\
Maine (C) & 60.000 & 0.5 \\
North Atlantic (D) & 60.000 & 0.9 \\
Norway (E) & 40.000 & 0.8 \\
Bay of Biscay (F) & 100.000 & 0.6 \\
Eastern Atlantic (G) & 50.000 & 0.3 \\
Mediterranean sea (H) & 200.000 & 0.2 \\
\hline
\end{tabular}

\section{Results}

4.1 Tuna migrations in a stable environment

We first run the model using only the demographic processes, without migration or environmental variability, and 
bioRxiv preprint doi: https://doi.org/10.1101/020743; this version posted June 10, 2015. The copyright holder for this preprint (which was not certified by peer review) is the author/funder, who has granted bioRxiv a license to display the preprint in perpetuity. It is made available under aCC-BY-NC-ND 4.0 International license.
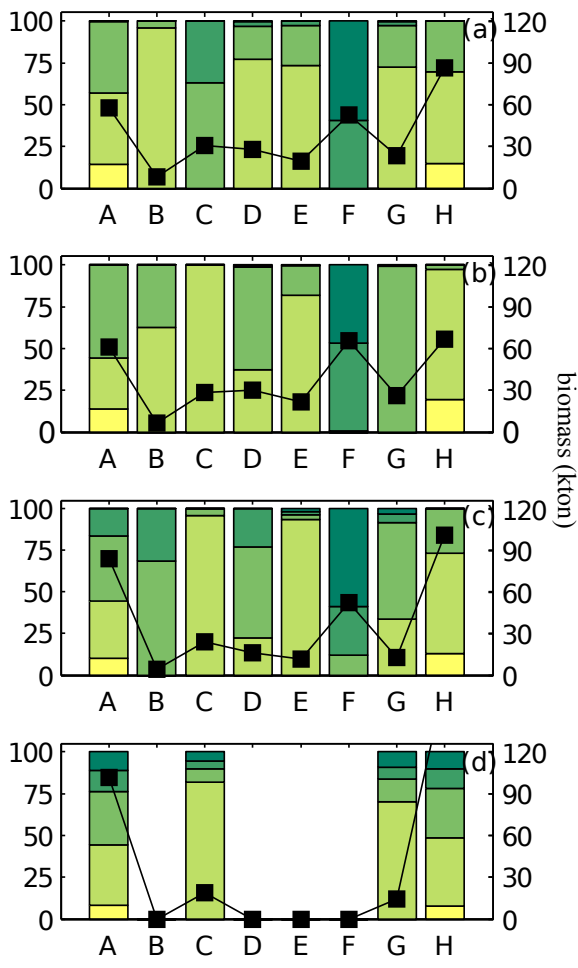

Habitat ID

Fig. 4 Total biomass (lines) and population structure (bars) in the bluefin tuna habitats as resulting from the equilibrium of the migration game when no demography or seasonal changes are considered in the model. The total biomass of the population is $330 \mathrm{kton}$ while habitat selection costs are (a) very low $\mu=20$, (b) low $\mu=50$, (c) medium $\mu=100$ and (d) high $\mu=150$. Different colours (yellow to dark green) for the 5 different age classes (Young to Old).

set the total bluefin tuna biomass $(M=330$ kton $)$. The 2 simulation converges towards a stable age-structure distribution in the spawning areas (Gulf of Mexico and Mediterranean) and zero biomass otherwise. This is the initial condition used in all the subsequent simulations.

From this initial distribution, we simulate the migration game in the case of a stable environment with no seasonality

8 ( $K_{i}$ constant, Table 2). We assume no demographic changes in the tuna population structure (i.e., the Leslie matrix is

10 the identity matrix) but consider different costs in the habitat selection process. Under such assumptions the migration 12 game on the network converges towards a stable distributional equilibrium (Figure 4).

14

At very low costs $(\mu=20)$ most of the biomass is aggregated in the spawning areas $\left(M_{A}=61\right.$ kton and $M_{H}=$

1689 kton $)$ and in the Bay of Biscay $\left(M_{F}=47\right.$ kton $)$ while the sum of all the other habitats accounts for $\approx 35 \%$ of the

18 total biomass (Figure $4 \mathrm{a}$ ). In this case largest tuna are on both sides of the Atlantic and mainly in habitats $C$ and $F$ 20 with Mediterranean and Gulf of Mexico showing the most structured population distribution. The youngest class (yel-
22 low color) is present only in the spawning areas and do not migrate in other habitats.

Increasing the habitat selection costs $(\mu=50$, Figure $4 \mathrm{~b})$ has no major effects on the biomass distribution. The distri26 butions of age classes are also similar to the previous case with relative changes only in habitats $G$ and $C$. With a fur28 ther increase of the cost $(\mu=100$, Figure $4 \mathrm{c})$ the population tends to accumulate in the spawning areas while the most 30 distant habitats tend to become unoccupied. At very high cost $(\mu=150$, Figure 4c) only few habitats are populated 32 and the majority of tuna biomass is in the spawning area $\left(M_{A}=102\right.$ kton, $M_{H}=172$ kton $)$.

\section{4.2 Migration game in a seasonal environment}

We simulate the habitat selection process under changing 36 carrying capacity $\left(K_{i}\right)$ and accounting for tuna population demography $(L(t)$, Eq. 6).

Seasonal fluctuations in the tuna biomass are evident in all patches with the weakest seasonality in the spawning habitats (Figure 5). The habitat in Norway (Figure 5E) and
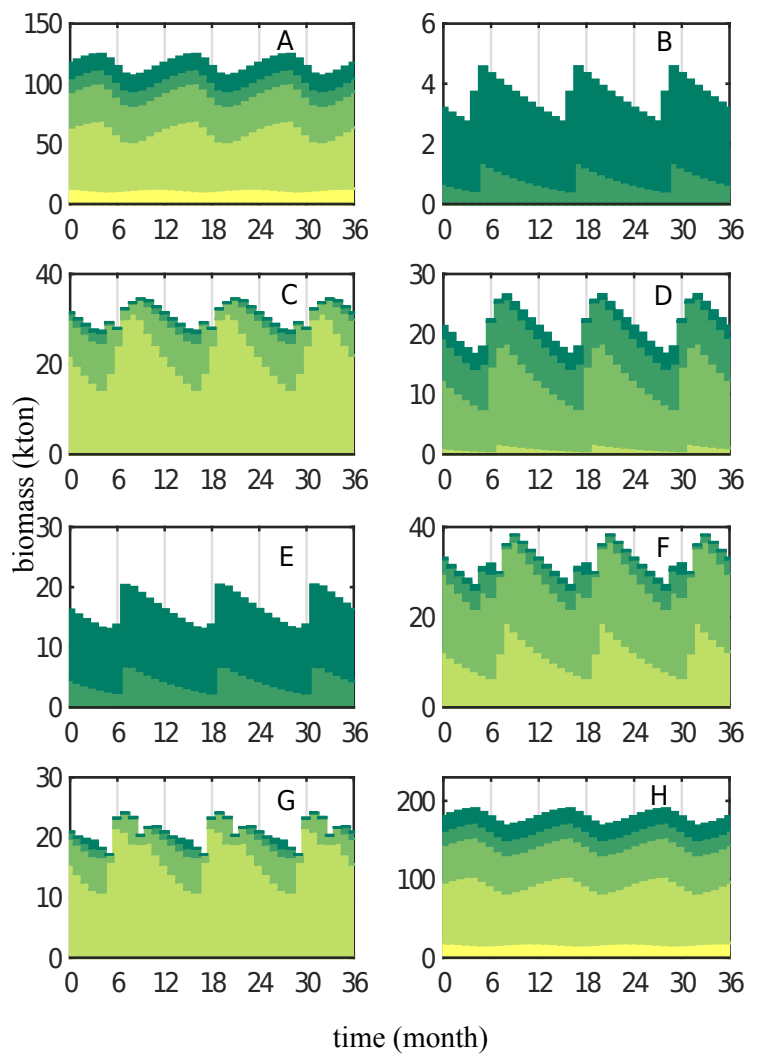

Fig. 5 Time series of the biomass per age in the 8 habitats $(A-H)$ at given habitat selection cost $(\mu=100)$ and spawning parameter $(s=$ 30). Different colours (yellow to dark green) for the 5 different age classes (Young to Old). 
Brazil (Figure $5 B$ ) are occupied by the larger/older classes, but have the lowest of the biomasses. The age-structure in each habitat changes less than the variability in total biomass, 4 but throughout the season significant changes in the agestructure can occur in the eastern Atlantic and Maine (Figure

$65 C, G)$. Interestingly the peaks in biomass in the spawning areas are in April - May while in the feeding areas are in July - August and late October in Brazil (Figure 5) as it is commonly reported (Table 4.2).

The intensity of migration on the habitat network depends on the cost of the habitat selection process and the 2 spawning intensity of the species (Figure 6). When costs are low and spawning intensity high (Figure 6a) the population

14 distributes in all available habitats and all migratory routes are used with the exception of the transatlantic route $\mathrm{C}$ -

${ }_{16}$ G. The age-structure is different in each area and highly diversified in the spawning area and in the central Atlantic. When the spawning intensity is reduced (Figure 6b) the total global biomass also decreases and some of the routes are used less frequently. In particular the connections between Brazil and the western Atlantic are much weaker but the

22 transatlantic connections (A - G and C - G) have higher migration flows. This is mainly driven by the very low biomass

24 living in the habitat in Brazil (Figure 6b). At higher habitat selection costs (Figure 6c,d) the direct transatlantic routes 26 connecting habitats $\mathrm{A}$ and $\mathrm{C}$ to $\mathrm{G}$ break down and generally there are low migration rates between habitats. Moreover, only larger individuals appear to exploit the farthest habitats B and E. Further increases of the costs, results in the 30 majority of the population staying in the spawning habitats. In these configurations habitats such as Brazil and Norway

32 have a very low biomass or are completely unoccupied. In the case of high cost and low spawning intensity the mi34 gration strategy is only selected by larger individuals while the majority of the population will not distribute outside 36 the spawning grounds. Most of these patterns are confirmed also when a more extensive sensitivity analyses is performed

38 (Appendix A.3).

\section{Discussions}

$40 \quad 5.1$ Migration modelling

We introduce a model based on game theory to simulate 42 habitat selection processes in migratory populations. The ${ }_{58}$ model is developed to describe migration dynamics in age-

44 structured fish populations and it is applied to study the sea- 60 sonal migration of the Atlantic bluefin tuna. The model ex-

46 plicitly represents habitat connectivity as a network with 62 several patches connected by links.

48 The results show how changes in the resource level, pop- 64 ulation demography and cost of migrations can alter the mi-
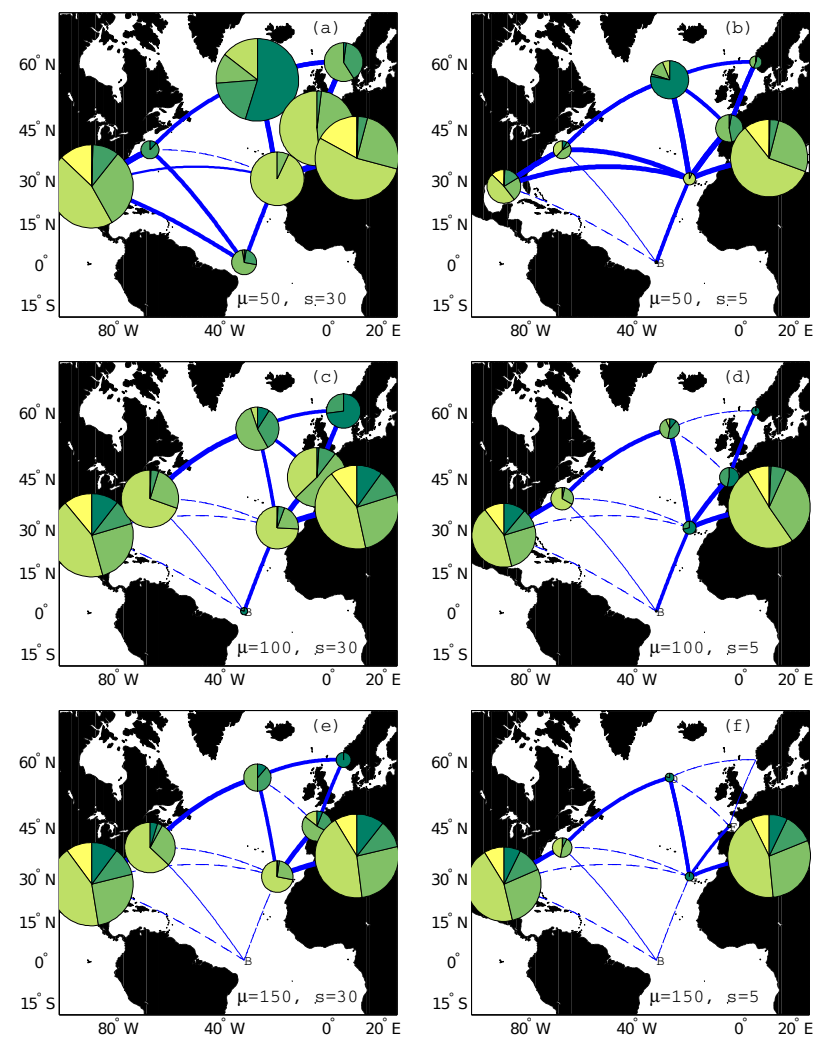

Fig. 6 Map of the network structure at different spawning intensity $(s)$ and habitat selection cost $\mu$. Simulations are run for 10 years under seasonal effects and the distribution in December is shown. Habitats are showed with circle proportional to the total tuna biomass and colour for different age (between yellow and dark green from Young to Old age, respectively). Lines connecting the habitats show integral biomass flux during the entire simulation and are thicker for larger fluxes, while dashed lines are used when no flow is simulated along the path. (a) $\mu=$ 50 and $s=30$ and a total global biomass $M=496$ kton, (b) $\mu=50$ and $s=5$ and $M=128$ kton, (c) $\mu=100$ and $s=30$ and $M=424$ kton, (d) $\mu=100$ and $s=5$ and $M=166$ kton, (e) $\mu=150$ and $s=30$ and $M=374$ kton, (f) $\mu=150$ and $s=5$ and $M=174$ kton.

population distributions in the habitats. We further show that effectively selected as migratory pathways while many other routes are not utilised. This allows us to identify emerging migration routes in fish populations and to compare the predictions with observed migration behaviour.

A fundamental assumption in the model is that migration is described as a multiple equilibrium process between different habitats. In the migration game, each individual in a given habitat can - in a single time step - move only to the neighbour habitats, i.e., those that are locally connected to the one where the individual is living. The migration occurs when there is an advantage to move, which in the model is described as a positive reward function. Since this function is negatively density dependent, its value is affected by the strategies of other individuals in the populations and it 
bioRxiv preprint doi: https://doi.org/10.1101/020743; this version posted June 10, 2015. The copyright holder for this preprint (which was not certified by peer review) is the author/funder, who has granted bioRxiv a license to display the preprint in perpetuity. It is made available under aCC-BY-NC-ND 4.0 International license.

Table 3 Seasonal migration phenology of bluefin tuna in the north Atlantic Ocean

\begin{tabular}{|c|c|c|c|c|}
\hline Years & Region & $\begin{array}{l}\text { Timing of presence } \\
\text { in northern feeding } \\
\text { areas }\end{array}$ & References & Notes \\
\hline 1999-2004 & $\begin{array}{l}\text { West Atlantic } \\
\text { (GOM- } \\
\text { Newfoundland); } \\
\text { Bay of Biscay }\end{array}$ & July-September & (Block et al, 2005) & $\begin{array}{l}\text { Data Storage Tags } \\
\text { (DSTs) }\end{array}$ \\
\hline $1981-2005$ & Bay of Biscay & $\begin{array}{l}\text { Day 180-230 } \\
\text { (approx.) }\end{array}$ & (Dufour et al, 2010) & $\begin{array}{l}\text { Timing of immigra- } \\
\text { tion to region based } \\
\text { on commercial } \\
\text { CPUE data }\end{array}$ \\
\hline $2005-2009$ & $\begin{array}{c}\text { NWAtlantic } \\
\text { (Maryland to Cape } \\
\text { Cod) }\end{array}$ & summer months & $\begin{array}{c}\text { (Galuardi and } \\
\text { Lutcavage, 2012) }\end{array}$ & $\begin{array}{l}\text { DSTs applied to ju- } \\
\text { veniles }\end{array}$ \\
\hline $1950 \mathrm{~s}-1970 \mathrm{~s}$ & Norwegian Sea & July-September & $\begin{array}{c}\text { (Aloncle et al, 1972; } \\
\text { Mather et al, 1995) }\end{array}$ & $\begin{array}{l}\text { Based on commer- } \\
\text { cial catch data. }\end{array}$ \\
\hline 2012 & $\begin{array}{l}\text { East Greenland } \\
\text { (Denmark Strait) }\end{array}$ & August-September & $\begin{array}{l}\text { (MacKenzie et al, } \\
\text { 2014) }\end{array}$ & $\begin{array}{l}\text { Based on bycatch } \\
\text { in commercial } \\
\text { mackerel fisheries }\end{array}$ \\
\hline $1996-2003$ & $\begin{array}{l}\text { Contl. shelfbreak } \\
\text { south of Iceland }\end{array}$ & $\begin{array}{l}\text { August-October } \\
\text { (few in November) }\end{array}$ & $\begin{array}{l}\text { (Olafsdottir and } \\
\text { Ingimundardottir, } \\
\text { 2003) }\end{array}$ & $\begin{array}{l}\text { Based on commer- } \\
\text { cial CPUE data }\end{array}$ \\
\hline $1950 \mathrm{~s}-1970 \mathrm{~s}$ & $\begin{array}{c}\text { Dogger Bank, North } \\
\text { Sea } \\
\text { North Sea }\end{array}$ & $\begin{array}{l}\text { Day 190-290 } \\
\text { (approx.) }\end{array}$ & $\begin{array}{l}\text { (Murray, 1932; } \\
\text { MacKenzie and } \\
\text { Myers, 2007) }\end{array}$ & $\begin{array}{l}\text { Based on at sea } \\
\text { observations of } \\
\text { schools; similar } \\
\text { patterns seen from } \\
1912-1922 \text {. } \\
\text { Based on commer- } \\
\text { cial fisheries }\end{array}$ \\
\hline & $\begin{array}{l}\text { Southern Gulf of St. } \\
\text { Lawrence, Canada }\end{array}$ & August-October & $\begin{array}{c}\text { (Vanderlaan et al, } \\
\text { 2014) }\end{array}$ & $\begin{array}{l}\text { Based on commer- } \\
\text { cial CPUE data }\end{array}$ \\
\hline 1996-2006 & $\begin{array}{l}\text { Whole west Atlantic } \\
\text { from G. Mexico- } \\
\text { Newfoundland, }\end{array}$ & Seasonal during year & (Walli et al, 2009) & DSTs \\
\hline
\end{tabular}

is also affected by the cost of assessing and commuting between different habitats. At each time step the population 22 tends to reach a local equilibrium by trying to equalise the

4 local reward functions. In some cases this equilibrium cannot be reached because there are not enough individuals liv- ${ }^{24}$

6 ing in a given habitat that can migrate towards connected habitats with a higher payoffs.

The assumption of describing habitat connectivity by dis-28 crete network structure is a generalisation of migration models assuming movements between all pairs of habitats $\left(a_{30}\right.$ fully connected graph). The network approach easily captures the existence of geographical, bioenergetic or life his- 32 tory constrains, which often break potential migration routes

14 (Henningsson and Alerstam, 2005; Alerstam et al, 2003; 34 Alerstam, 2001). The model is also flexible enough to al-

${ }_{16}$ low the effects of ocean currents, temperature variability, or ${ }_{36}$ other environmental changes to be represented using differ-

18 ent costs on each link. Indeed, the cost of migration between 38 two habitats can affect the reward function and then can nism which is in agreement with the hypotheses that changes in migration routes can be driven by climate change (Walther et al, 2002; Rijnsdorp et al, 2009; Doney et al, 2012).

The ability to equalise the local reward functions and reach an equilibrium is consistent with the ideal free distribution theory (Fretwell and Lucas, 1969). We show that at each time step individuals in the population distribute according to a local IFD among connected habitats and, in case of stable environment with no demographic effects, the local equilibrium converges, in several steps, towards a global IFD on the network (Pan and Nagurney, 1994; Cressman and Krrivan, 2006). The behaviour dynamic we use in the model describes when and how individuals update their strategies over time. This is known as revision protocol in game theory (Sandholm, 2010) and is based on two assumptions: myopia and inertia. A myopic behaviour means that individuals assess their strategy based on local information on costs and payoff opportunities, without incorporating knowledge on future expectations and behaviours. Inertia in behaviour considers that individuals do not update their strategy con- 
tinuously but instead re-evaluate their decision sporadically, 52 mainly because very often the environment in which they live provides a multiplicity of concerns to be solved rather 4 than a single-minded focus on one strategy (Sandholm, 2010) $)_{54}$ We think that the discrete form of time and space in our 6 model describes naturally myopic and inertial processes whicda are likely to occur in fish populations. Moreover, compared

8 to a continuous model, the discrete representation of the 58 space with the network of habitats appears to be more con-

10 sistent with the idea of migration corridors, habitat hot spots 60 and migration stopovers which are typically found in many

12 species (Rose, 1993; Hunter et al, 2003).

\subsection{Environmental and demographic effects}

14 Seasonality in the resource distribution and competition for ${ }^{66}$ resources are both important mechanisms for the selection

16 of migration as a behavioural trait. Indeed, in weak seasonal ${ }^{68}$ environments and under low competition conditions, resi-

18 dency is the behavioural strategy that is selected (Shaw and ${ }^{70}$ Couzin, 2013). Our results support those findings and show

20 that in case of a stable environment the distribution of the populations between heterogeneous habitat converges to the

22 IFD. At the IFD there is no net dispersal between habitats ${ }^{74}$ unless demographic effects are present. Indeed changes in tions then allowing migrations to emerge. The coupling be-

26 tween demographic and environmental effects are critical ${ }^{78}$ for the results. Generally, if dispersal dynamics are much

${ }_{28}$ faster than the changes in the habitats payoff, the IFD can ${ }^{80}$ still be reached by migratory species. But if migrations and

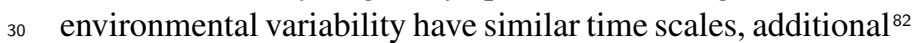
assumptions need to be made on dispersal (Mobæk et al,

32 2009; McLoughlin et al, 2010). In our model we assume that ${ }^{84}$ the population can reach a local IFD condition, which trans-

34 lates into assuming a fast behavioural response to explore ${ }^{86}$ neighbour habitats. The time step used to integrate the dis-

36 crete model sets the time scales for behavioural response and ${ }^{88}$ environmental variability. An alternative approach would de-

38 scribe demographic and environmental dynamics as contin- 90 uous processes both affecting the migratory behaviour with

40 feedback on the population dynamics. In such cases how- 92 ever we would have a revision protocol lacking the inertia

42 of the decision process which we think is common in most 94 natural populations.

The presented model does not explicitly account for the 96 feedbacks between migration dynamics and demographic

46 processes. Indeed, in habitats with higher payoff one could 98 expect individuals to grow faster than those in lower payoff

48 habitat. To capture the impacts of a large payoff on individ-100 ual growth, one would likely require an individual-based-

50 approach to store information about memory and history of $f_{102}$ the single individuals.
5.3 Relevance to the ecology of the Atlantic bluefin tuna

As we have seen before, Atlantic bluefin tunas have a wide distribution in the Atlantic Ocean from tropical to sub-polar areas. Migration has likely evolved to allow migrants to benefit from the highly productive environment at higher latitude while reducing competition by moving towards less productive environments. Being excellent swimmers bluefin tuna can potentially be present in all parts of the Atlantic. Nonetheless, several evidences suggest that the species distributes within several hotspots areas, where tunas are present all year round, while their abundance outside those areas are minimal. Moreover, the same individual can visit these hotspots several times during the feeding period before going back to spawning areas for reproduction. Those patterns in distribution and migration behaviour are in part captured by the habitat network approach used in our model, with a series of hotspot areas connected by a range of migratory pathways. Moreover, the model appears to describe reasonably well the peaks in distribution in the different areas. For example in the spawning areas the maximum abundance is mainly at the beginning of summer and precedes the peaks in abundances in the feeding areas. Habitats such as Norway or Brazil are visited only by the larger individuals (200-500 $K g$ ) and are very sensible to changes in fishing pressure or cost of migrations (Fromentin, 2009; Safina and Klinger, 2008).

Thus our modelling approach allows representing in a quite realistic way the spatial population dynamics of the Atlantic bluefin tuna including simulating the disappearance of previous feeding habitats and changes in migration routes.

The modelled estimate of the timing of appearance at summer feeding areas is similar to the migration phenology to many of these areas observed in nature (Table 4.2). In addition, the size composition of the modelled populations arriving in several of these areas compares favourably with the size composition of bluefin tuna observed and / or caught in such regions.

For example, modelled size distributions for Brazil and Norway are centred at large $(\approx 200 \mathrm{~cm})$ sizes; catch data from these areas (Mather et al, 1995) shows that most bluefin captured in fisheries in these areas were generally $>150$ $200 \mathrm{~cm}$, thus similar to modelled estimates.

Our modelling approach is potentially a useful framework for investigating how exploitation and environmental variability including climate change could affect the largescale migratory behaviour and spatial distribution of bluefin tuna and its phenology. For example, environmentally driven changes in regional productivity and carrying capacity would affect habitat suitability, migration costs (e.g., due to temperature changes) and migratory rewards after arriving at destinations. These changes could lead to reductions of utilisation of some habitats and stronger preferences for habi- 
bioRxiv preprint doi: https://doi.org/10.1101/020743; this version posted June 10, 2015. The copyright holder for this preprint (which was not certified by peer review) is the author/funder, who has granted bioRxiv a license to display the preprint in perpetuity. It is made available under aCC-BY-NC-ND 4.0 International license.

tats in other regions, thereby potentially influencing fishery opportunities and costs for different nations. Such changes may already be underway because migration phenology for 52

4 the Bay of Biscay is linked to large-scale climate conditions (e.g., the North Atlantic Oscillation, NAO) that af- 54 fect sea temperatures (Dufour et al, 2010) and bluefin tuna have recently been observed in east Greenland where they 56 have not previously been observed (MacKenzie et al, 2014). Moreover our modelling framework, if coupled to integrated 58 o oceanographic biogeochemical models (Dragon et al, 2015), could also potentially be used to derive new insights on the 60 12 relative roles of oceanographic variability and exploitation leading to past major changes in bluefin tuna distributions 62 14 and fisheries such as those off Brazil, Norwegian-North Sea and south of Iceland. Recent advances in group behaviour 64 and information sharing/transfer between individuals within groups also show how habitat choice can be influenced by 66 als within groups, and how group behaviour (e.g., migration 68 20 to particular habitats) can be driven by a subset of informed individuals (De Luca et al, 2014).

A future challenge for migratory behaviour modelling is therefore to develop ways to integrate individual-level and ${ }^{74}$ 24 group dynamics in migration game modelling frameworks such as that developed here. Given that bluefin tuna is such 76 26 a highly migratory species, and migrates across ocean zoning boundaries of several jurisdictions, and also across stock ${ }^{78}$ 28 management boundaries, migration models that quantify rates and timing of exchanges among areas could potentially have 80 30 practical application in fishery management and conservation. The migratory behaviour of this species is complex. ${ }^{82}$ 32 Our modelling approach, although moderately complex, is based on some simplified considerations of population dy- 84 34 namics, regionally-dependent ecosystem carrying capacities and bioenergetics of energy intake and utilisation, and is ${ }^{86}$ a step towards process-oriented migration and distribution models. Further advances in process knowledge and imple- 88 38 mentation are needed, and if implemented, could support management and conservation decision-making for this species.

40 Acknowledgements The Authors wish to thank the participants to the conference 'Dispersal and competition of populations and communi-

42 ties in spatially heterogeneous environments', Lausanne, Switzerland, 96 4-8 August 2014 for inspiring some of this work. PM received support

44 from Otto Mønsted Fond and was supported by the European Union Seventh Framework Programme project EURO-BASIN (ENV.2010.2.2.1-

46 1) under grant agreement nr. 264933. This work was partly conducted while VK was a Sabbatical Fellow at the Mathematical Biosciences100

48 Institute, an Institute sponsored by the National Science Foundation under grant DMS 0931642. Support provided by the Institute of Ento50 mology (RVO:60077344) is acknowledged.

\section{References}

Alerstam T (2001) Detours in bird migration. Journal of Theoretical Biology 209(3):319-331

Alerstam T, Hedenström A, Åkesson S (2003) Longdistance migration: evolution and determinants. Oikos 103(2):247-260

Aloncle H, Hamre J, Rodriguez-Roda J, Tiews K (1972) Report from the bluefin tuna working group. Observations on the size composition of bluefin tuna catches

Åström M (1994) Travel cost and the ideal free distribution. Oikos 69(3):516-519

Block BA, Stevens ED (2001) Tuna: physiology, ecology, and evolution, vol 19. Gulf Professional Publishing

Block Ba, Dewar H, Blackwell SB, Williams TD, Prince ED, Farwell CJ, Boustany a, Teo SL, Seitz a, Walli a, Fudge D (2001) Migratory movements, depth preferences, and thermal biology of atlantic bluefin tuna. Science (New York, NY) 293(5533):1310-4, DOI 10.1126/science.1061197

Block BA, Teo SLH, Walli A, Boustany A, Stokesbury MJW, Farwell CJ, Weng KC, Dewar H, Williams TD (2005) Electronic tagging and population structure of Atlantic bluefin tuna. Nature 434(7037):1121-7, DOI 10.1038/nature03463, URL http://www.ncbi.nlm.nih.gov/pubmed/15858572

Bonte D, Van Dyck H, Bullock JM, Coulon A, Delgado M, Gibbs M, Lehouck V, Matthysen E, Mustin K, Saastamoinen M, et al (2012) Costs of dispersal. Biological Reviews 87(2):290-312

Cody ML (1985) Habitat selection in birds. Academic Press Cressman R, Křivan V (2006) Migration dynamics for the ideal free distribution. The American Naturalist 168(3):384-397

Cury P, Anneville O, Bard F, Fonteneau A, Roy C (1998) Obstinate North Atlantic bluefin tuna (Thunnus thynnus thynnus): an evolutionary perspective to consider spawning migration. Collective volume of scientific papers, ICCAT 50(1):239-247

De Luca G, Mariani P, MacKenzie BR, Marsili M (2014) Fishing out collective memory of migratory schools. Journal of The Royal Society Interface 11(95):20140,043

92 Dewar H, Graham J (1994) Studies of tropical tuna swimming performance in a large water tunnel-energetics. Journal of Experimental Biology 192(1):13-31

Doney SC, Ruckelshaus M, Emmett Duffy J, Barry JP, Chan F, English CA, Galindo HM, Grebmeier JM, Hollowed AB, Knowlton N, et al (2012) Climate change impacts on marine ecosystems. Annual review of marine science 4:11-37

Dragon AC, Senina I, Titaud O, Calmettes B, Conchon A, Arrizabalaga H, Lehodey P, Jacobson L (2015) An ecosystem-driven model for spatial dynamics and stock 
bioRxiv preprint doi: https://doi.org/10.1101/020743; this version posted June 10, 2015. The copyright holder for this preprint (which was not certified by peer review) is the author/funder, who has granted bioRxiv a license to display the preprint in perpetuity. It is made available under aCC-BY-NC-ND 4.0 International license.

assessment of north atlantic albacore. Canadian Journal 54 of Fisheries and Aquatic Sciences 72(999):1-15

Dufour F, Arrizabalaga H, Irigoien X, Santiago J (2010) Cli- 56 mate impacts on albacore and bluefin tunas migrations phenology and spatial distribution. Progress in Oceanog- 58 raphy 86(1):283-290

Facchinei F, Pang JS (2003) Finite-dimensional varia- 60 tional inequalities and complementarity problems, vol 1. Springer Science \& Business Media

10 Fretwell SD, Lucas HL (1969) On territorial behavior and other factors influencing habitat distribution in birds. Acta 64 biotheoretica 19(1):16-32

Fromentin JM (2009) Lessons from the past: in- 66 vestigating historical data from bluefin tuna fisheries. Fish and Fisheries 10(2):197-216, 68 DOI 10.1111/j.1467-2979.2008.00311.x, URL http://doi.wiley.com/10.1111/j.1467-2979.2008.00311.x 70

Galuardi B, Lutcavage M (2012) Dispersal routes and habitat utilization of juvenile atlantic bluefin tuna, thunnus 72 thynnus, tracked with mini psat and archival tags. PloS one 7(5):e37,829

22 Grand TC, Dill LM (1999) Predation risk, unequal competitors and the ideal free distribution. Evolutionary Ecology 76 Research 1:389-409

Henningsson SS, Alerstam T (2005) Barriers and distances 78 as determinants for the evolution of bird migration links: the arctic shorebird system. Proceedings of the Royal So- 80 ciety B: Biological Sciences 272(1578):2251-2258

Hugie D, Dill L (1994) Fish and game: a game theoretic ap- 82 proach to habitat selection by predators and prey. Journal of Fish Biology 45:151-169

32 Hugie DM, Grand TC (1998) Movement between patches, unequal competitors and the ideal free distribution. Evo- 86 lutionary Ecology 12:1-19

Hunter E, Metcalfe JD, Reynolds JD (2003) Migration route 88 and spawning area fidelity by north sea plaice. Proceedings of the Royal Society of London B: Biological Sci- 90 ences 270(1529):2097-2103

Kennedy M, Gray RD (1993) Can ecological theory predict 92 the distribution of foraging animals? a critical analysis of experiments on the ideal free distribution. Oikos pp 158-94 166

Křivan V, Cressman R, Schneider C (2008) The ideal free 96 distribution: a review and synthesis of the game-theoretic perspective. Theoretical Population Biology 73(3):403-98 425

MacArthur R, Levins R (1964) Competition, habitat selec-100 tion, and character displacement in a patchy environment. Proceedings of the National Academy of Sciences of the ${ }_{102}$ United States of America 51(6):1207

MacCall AD (1990) Dynamic geography of marine fish pop-104 ulations. Washington Sea Grant Program Seattle, Washington
MacKenzie BR, Myers RA (2007) The development of the northern european fishery for north atlantic bluefin tuna thunnus thynnus during 1900-1950. Fisheries Research 87(2):229-239

MacKenzie BR, Payne MR, Boje J, Høyer JL, Siegstad H (2014) A cascade of warming impacts brings bluefin tuna to greenland waters. Global change biology 20(8):24842491

Mather FJ, Mason JM, Jones AC (1995) Historical document: life history and fisheries of Atlantic bluefin tuna. Tech. rep., US Dept. of Commerce, National Oceanic and Atmospheric Administration, National Marine Fisheries Service, Miami

Matsumura S, Arlinghaus R, Dieckmann U (2010) Foraging on spatially distributed resources with sub-optimal movement, imperfect information, and travelling costs: departures from the ideal free distribution. Oikos 119(9):1469-1483, DOI 10.1111/j.1600-0706.2010.18196.x, URL http://doi.wiley.com/10.1111/j.1600-0706.2010.18196.x

McLoughlin PD, Morris DW, Fortin D, Vander Wal E, Contasti AL (2010) Considering ecological dynamics in resource selection functions. Journal of Animal Ecology 79(1):4-12

Mobæk R, Mysterud A, Egil Loe L, Holand Ø, Austrheim G (2009) Density dependent and temporal variability in habitat selection by a large herbivore; an experimental approach. Oikos 118(2):209-218

Morris DW (2011) Adaptation and habitat selection in the eco-evolutionary process. Proceedings Biological sciences / The Royal Society 278(1717):2401-2411, DOI 10.1098/rspb.2011.0604, URL http://www.ncbi.nlm.nih.gov/pubmed/21613295

Mullon C (2013) Network economics of marine ecosystems and their exploitation. CRC Press

Mullon C, Nagurney A (2012) A game theoretical approach to the vertical coexistence of small and big fish. Ecological Modelling 240:41-48

Murray DW (1932) Tunny (thunnus thynnus 1.) in the north sea. Journal du Conseil 7(2):251-254

Nagurney A (1993) Network Economics. A variational inequality approach. Kluwer Academic Publishers, Dordrecht

Nagurney A, Pan J, Zhao L (1992) Human migration networks. European journal of operational research 59(2):262-274

Olafsdottir D, Ingimundardottir T (2003) Age-size relationship for bluefin tuna (thunnus thynnus) caught during feeding migrations to the northern n-atlantic. Col Vol Sci Pap ICCAT 55(3):1254-1260

Overholtz W (2006) Estimates of consumption of atlantic herring (clupea harengus) by bluefin tuna (thunnus thynnus) during 1970-2002: an approach incorporating uncer- 
bioRxiv preprint doi: https://doi.org/10.1101/020743; this version posted June 10, 2015. The copyright holder for this preprint (which was not certified by peer review) is the author/funder, who has granted bioRxiv a license to display the preprint in perpetuity. It is made available under aCC-BY-NC-ND 4.0 International license.

tainty. J Northwest Atl Fish Sci 36:55-63

2 Pan J, Nagurney A (1994) Using markov chains to model 54 human migration in a network equilibrium framework. Mathematical and computer modelling 19(11):31-39 56

Rijnsdorp AD, Peck MA, Engelhard GH, Möllmann C, Pinnegar JK (2009) Resolving the effect of climate change on 58 fish populations. ICES Journal of Marine Science: Journal du Conseil p fsp056

Rose GA (1993) Cod spawning on a migration highway in the north-west atlantic. Nature 366(6454):458-461 62

Rosenzweig ML (1981) A theory of habitat selection. Ecology 62(2):327-335

Rosenzweig ML, Abramsky Z (1985) Detecting densitydependent habitat selection. American Naturalist pp 405-66 417

16 Safina C, Klinger DH (2008) Collapse of bluefin tuna in the 68 western atlantic. Conservation Biology 22(2):243-246

18 Sandholm WH (2010) Population games and evolutionary 70 dynamics. MIT press

20 Schreiber SJ (2012) The evolution of patch selection in stochastic environments. The American Naturalist 180(1):17-34

SCRS (2012) Report of the 2012 atlantic bluefin tuna stock

24 assessment session. Tech. Rep. SCI-033 / 2012, ICCAT

Shaw AK, Couzin ID (2013) Migration or residency? the evolution of movement behavior and information usage in seasonal environments. The American Naturalist 181(1):114-124

Simon M, Fromentin JM, Bonhommeau S, Gaertner D, Brodziak J, Etienne MP (2012) Effects of stochasticity in early life history on steepness and population growth rate estimates: An illustration on atlantic bluefin tuna. PloS one 7(10):e48,583

34 Sutherland WJ, Parker GA (1985) Distribution of unequal competitors. In: Sibly RM, Smith RH (eds) Behavioural Ecology, Blackwell, Oxford, pp 255-273

Tiews K (1978) On the disappearance of bluefin tuna in the north sea and its ecological implications for herring and mackerel. Rapports et Proces-Verbaux des Reunions (Denmark)

Tregenza TOM, Thompson DJ (1998) Unequal competitor ideal free distribution in fish ? Evolutionary Ecology 12:655-666

44 Vanderlaan AS, Hanke AR, Chassé J, Neilson JD (2014) Environmental influences on atlantic bluefin tuna (thunnus thynnus) catch per unit effort in the southern gulf of st. lawrence. Fisheries Oceanography 23(1):83-100

48 Walli A, Teo SL, Boustany A, Farwell CJ, Williams T, Dewar H, Prince E, Block BA (2009) Seasonal movements, aggregations and diving behavior of atlantic bluefin tuna (thunnus thynnus) revealed with archival tags. PLoS One 4(7):e6151
Walther GR, Post E, Convey P, Menzel A, Parmesan C, Beebee TJ, Fromentin JM, Hoegh-Guldberg O, Bairlein F (2002) Ecological responses to recent climate change. Nature 416(6879):389-395

Ware D (1978) Bioenergetics of pelagic fish: theoretical change in swimming speed and ration with body size. Journal of the Fisheries Board of Canada 35(2):220-228

Wecker SC (1963) The role of early experience in habitat selection by the prairie deer mouse, peromyscus maniculatus bairdi. Ecological Monographs 33(4):307-325

Westberry T, Behrenfeld M, Siegel D, Boss E (2008) Carbon-based primary productivity modeling with vertically resolved photoacclimation. Global Biogeochemical Cycles 22(2):GB2024

Wilson S, Lutcavage M, Brill R, Genovese M, Cooper A, Everly A (2005) Movements of bluefin tuna (thunnus thynnus) in the northwestern atlantic ocean recorded by pop-up satellite archival tags. Marine biology 146(2):409-423 
bioRxiv preprint doi: https://doi.org/10.1101/020743; this version posted June 10, 2015. The copyright holder for this preprint (which was not certified by peer review) is the author/funder, who has granted bioRxiv a license to display the preprint in perpetuity. It is made available under aCC-BY-NC-ND 4.0 International license.

\section{A Model calibration for Atlantic bluefin tuna}

\section{A.1 Migration costs}

The time needed to migrate between two habitats regulates the cost of 4 migration in fish population since the energy consumed will be higher the longer is the migration time. The power rate consumed while swim6 ming at an optimal speed $(P)$ is:

$P=\alpha_{0} w^{\eta} U^{\beta}$

where $w$ is the weight of the fish, while the allometric constants $\alpha_{0}$ and $\eta$ have been estimated for fish swimming at high Reynolds number (Ware, 1978, Table 4)

10 We can fairly assume that migrations is performed at an optimal swimming speed $\left(U^{*}\right)$ at which the total energy expenditure per unit 12 distance is minimised. Using an allometric function for the metabolic costs $M=\alpha_{1} w^{\gamma}$, a general form of $U^{*}$ can be derived by an optimisa-

14 tion procedure relating the swimming cost to the total cost of moving (metabolic cost plus power output):

$U^{*}=\left[\frac{-\alpha_{1} w^{\gamma}}{\alpha_{0} w^{\eta}(1-\beta)}\right]^{\frac{1}{\beta}}$

where $\alpha_{1}$ and $\gamma$ are allometric constants for fish metabolism (Table 4). This results in an allometric scaling for the optimal swimming 18 speed as:

$U^{*} \approx w^{\frac{\gamma-\eta}{\beta}}$

In tuna the exponent $\beta$ has been found to range between $1.4<\beta<2.8$

20 (Dewar and Graham, 1994) and we assume $\beta=2.1$, which provides swimming speeds in the range reported for several tuna species $(1.2-$ $22 \quad 2.4 B L s^{-1}$ ) (Block and Stevens, 2001).

Thus we obtain a scaling $U^{*} \approx w^{0.06}$.

\section{A.2 Demography}

Large uncertainties exist on the definition of demographic parameters

26 for the bluefin tuna population (Simon et al, 2012). In our model, the young-of-the-year stage ( 0 - 1 years) is excluding egg phases and does

28 not have reproductive potential while at juvenile stage ( $1-5$ years $)$ a small fraction is mature for reproduction. The reproductive maturity

30 increases up to $50 \%$ at the adult stage (5-10 years) while mature (10 - 20) and old (20 - 35) stages are fully reproductive but the latter has

32 a lower survival rate. Those rates are consistent with observed maturity at age data for western and eastern atlantic bluefin tuna (SCRS,

34 2012) and are used to define the values of $r_{k}$. Moreover, the value sur$\operatorname{vival}(q)$ and growth $(g)$ values used in the Leslie matrix are consistent 36 with reported values for the yearly mortality rates (SCRS, 2012) and provide a realistic bluefin tuna age-structure (Fig. 7) with a maximum population growth rate $(0.15)$ that is in the range of previous estimates (Simon et al, 2012). Finally, we constrain the global bluefin tuna pop-

ulation using a given total carrying capacity $K_{t}$ and assume a density dependent function on the spawning factor $s$.

\section{$42 \quad$ A.3 Extended Sensitivity analyses}

At low spawning intensity and high migration costs (Figure 8g) only 44 the spawning areas are occupied. Decreasing habitat selection costs allows tuna to migrate in adjacent feeding areas $(\mathrm{G}$ and $\mathrm{C})$ but reduce

46 the total biomass and increase fluctuations in the migration behaviour (Figure 8a,d) . On the other hand, at high spawning and low migration

48 costs (Figure 8a,b) the biomass reaches the total carrying capacity over few months, and all habitats are occupied although at different levels 50 of biomass.

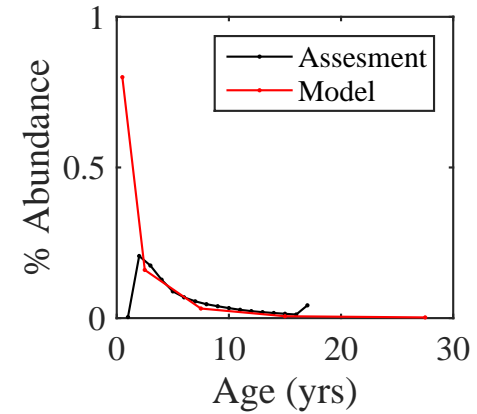

Fig. 7 Age structure data from the ICCAT assessment group (black) on bluefin tuna and from the model using the Leslie matrix estimates (red).

\begin{tabular}{llll}
\hline Parameter & Symbol & Value & Ref. \\
\hline Max. Energy intake & $I(w)$ & $c w^{\phi}$ & - \\
Standard metabolic rate & $M(w)$ & $\alpha_{1} w^{\gamma}$ & - \\
Swimming power & $P(w)$ & $\alpha_{0} w^{\eta} U^{\beta}$ & - \\
\hline Constant for energy intake & $\mathrm{c}$ & $1 \cdot 10^{-2}$ & {$[1]$} \\
Exponent for energy intake & $\phi$ & 0.8 & {$[1]$} \\
Constant for power cost & $\alpha_{0}$ & $1.8 \cdot 10^{-8}$ & {$[2]$} \\
Exponent for power cost & $\eta$ & 0.47 & {$[2]$} \\
Exponent for power cost & $\beta$ & $1.4<\beta<2.8$ & {$[3]$} \\
& & $(\beta=2)$ & \\
Constant for metabolic cost & $\alpha_{1}$ & $3.76 \cdot 10^{-4}$ & {$[4]$} \\
Exponent for metabolic cost & $\gamma$ & 0.6 & {$[4]$} \\
\hline
\end{tabular}

Table 4 Scaling of physiological rates with size and parameter values for tuna from: [1] Overholtz (2006) [2] Ware (1978) [3] Dewar and Graham (1994) [4] Block and Stevens (2001)
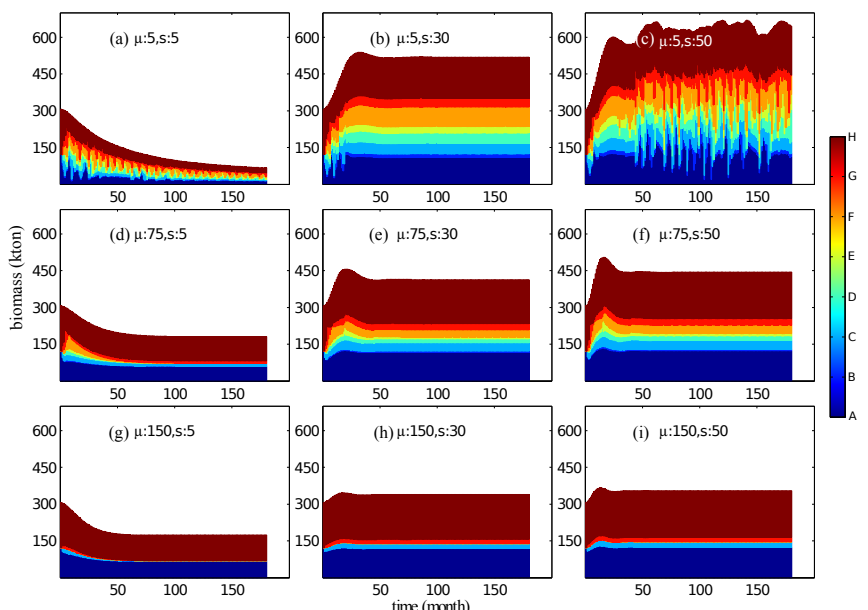

Fig. 8 Sensitivity of the population structure and total biomass in different habitats in case of no seasonality and zero fishing under different spawning intensity s and habitat selection cost $\mu$. 